INTERNATIONAL JOURN AL OF RESEARCHES IN BIOSCIENCES, AGRICULTURE AND TECHNOLOGY (c) VISHWASHANTI MULTIPURPOSE SOCIETY (Global Peace Multipurpose Socie ty) R. No. MH-659/13 (N) www.vmsindia.org

\title{
LYTOCESTUS GODAVARIENSIS N.SP. FROM FRESHWATER FISH CLARIAS BATRACHUS FROM GODAVARI RIVER AT PRAVARASANGAM, TALUKA NEWASA, DISTRICT AHMEDNAGAR, M.S.
}

\author{
R. G. Pawar ${ }^{1}$, R. R. Dandawate ${ }^{2}$ and R. S. Lonkar ${ }^{2}$ \\ 1Dept. of Zoology, S.S.G.M. College, Kopargaon, Dist- Ahmednagar, M.S. \\ ${ }^{2}$ Dept. of Zoology, Arts, Commerce and Science College, Sonai, Tal- Newasa, Dist- Ahmednagar,M.S. \\ d_rajendra2006@rediffmail.com
}

\begin{abstract}
:
The present study deals survey of cestode parasites from fresh water fishes like Clarius batrachus from Godavari rive $r$ at Pravarasangam in district Ahmednagar during January 2012 to December 2012.The present communication deals with the new species godavariensis from the genus Lytocestus is worm having head long. Testes numerous (400-500) in numbers. Cirrus pouch small, oval, pre-ovarian, transversally placed, cirrus straight thin, vagina long, coiled tube, vas deferens short, thin. Genital pores small, oval, obliquely placed. Ootype is s mall and oval. Ovary bilobed, on posterior side, each lobe contains 24-26 ovarian follicles, two lobe s connected to each other by isthmus. Uterus wide convoluted tube filled with numerous eggs. Uterine pore is median and rounded. Eggs are ope rculated, oval in shape. Vitellaria are granular and corticular in position.

Keywords: Ly tocestus, Clarias batrachus, Godavari River.
\end{abstract}

\section{Introduction}

The genus Lytocestus was erected by Cohn (1908) with its type species. L.adhaerens found in Clarias fuscus in Hong-Kong. This genus was first confirmed by Woodland (1926), who included four more species in addition to the type species. They are L. filiformes Woodland (1923) in Mormynus caschive Egyption Sudan $L$. calmersius (Woodland, 1924), L. cunnigtoni Fuhrmann and Bear (1925) and L. indicus Moghe (1925) (syn. Caryophyllaeces indicus) from Clarias batracus in India. The same species was recorded by Mehra (1930) from Clarias magur and Ramdevi (1973) from Clarias batracus in India, Hunter (1927) placed the genus in sub-family of his own namely Lytocestinae and retained only three species i.e. L.adhaerens, $L$. filiformes and $L$. indicus. He put the species $L$. cunningtoni and $L$. calmersius in the genus. Monobothrioides. Subsequent work of Gupta (1961), Murhar (1963) have adhered to these changes. Wardle and McLeod (1952) followed Hunter's classification but raised the status of Lytocestinae from sub-family to family, Wardle, McLeod and Radinovsky (1974) suggested a new system of classification of cestodes, who used the term cotyloda as a class and order caryophyllidae is kept in this class MACKIEWICZ (1972) INCLUDED THE SPECIES L. javanicus (Bovien, 1926), Fartado (1963), Lynsdale (1950) considered L. alestesi as syn. Of L. barmanicus, Lynsdale (1956), but Mackiewicz (1962) after examination of original material L. alestesi Lynsdale (1956) concluded that it should be considerd as synonym of $L$. filiformis Woodland (1923), Ramdevi (1973) described L. longicollis from Clarias batrachus in India.

Later on Shinde and Phad erected $L$. marathwadensis from Clarias batrachus in (1988). Jadhav and Gavhane added L. alli as well as L. clariasae in Clarias batrachus (1991) from India. L. naldurgensis erected by Kadam, Hiware and Jadhav (1991) in Clarias batrachus. L. teranaensis was erected in 1999 by Kolpuke and Shinde in Wallago attu. Recently $L$. caryophyllid was added by D.N. Patil and B.V. Jadhav (Dec. 2002) in the host Clarias batrachus. Later in 2002 Shinde and Pawar added L. batrachusae. Later in 2004, L. shindei was erected by Khadap, Jadhav and Suryavanshi. Tandom et. Al. in 2005 erected four new species $L$. clariae, $L$. allenuateus, $L$. assamensis in Clarias batrachus and $L$. heteropneustii in Heteropneustes fossilis. Later on no species is added to this genus.

\section{Materials and Methods}

The present study deals survey of cestode parasites from fresh water fishes like Clarias batrachus from Godavari River at Pravarasangam in district Ahmednagar during January 2012 to December 2012 and brought in to laboratory. The worms were flattened, preserved in $4 \%$ formalin, stained with Harris he matoxyline, passed through various alcoholic grades, cleared in xylol, mounted in D.P.X. All 
drawing was drawn to scale with the aid of camera lucida and wholemount slides were prepared for anatomical and morphological studies. All measurements are in millimeter.

\section{Description}

Three hundred and eleven specimens of the cestode parasites were collected from the intes tine of Clarias batrachus (Linneus, 1758) at Pravarasngam, Tal Newasa, Dist. Ahmednagar, M.S. India, during the period of Jan 2012 to Dec. 2012. Out of the se fifteen were stained for taxonomical studies.

The mature, flattened specimens are long and measures 124. 100-24.230mm in length and 2.100 to $4.200 \mathrm{~mm}$ in weadth. The head is long, well marked off from the body and measures 3.116(2.385-3.847) in length and $1.999(0.727-2.271)$ in width.The testes are numerous (400-500) in numbers, pre-ovarian, placed centrally, evenly distributed, round to oval in shape, small in size and measures $0.151(0.121-0.182)$ in length and 0.103(0.091$0.114)$ in width.

The cirrus pouch is small, oval preovarian, transversely placed and measures 0.121 (0.114-0.129) in le ngth and 0.019 (0.0150.023 ) in width. The cirrus is straight, thin and measures 0.057 (0.053-0.060) in length and $0.012(0.005-0.015)$ in width. Vagina is a long, coiled tube, starts from genital pores and runs posteriorly in the body, measures $0.084(0.076$ $0.098)$ in length and $0.012(0.005-0.015)$ in width. The vas deferens is short, thin and measures $0.055(0.053-0.058)$ in length and $0.075(0.005-0.01)$ in width. Ootype is small, oval, situated in between the ovarian lobes and measures $0.0141(0.114-0.167)$ in length and $0.121(0.098-0.144)$ in width.

Ovary is bilobed, present at the posterior region of the body. Each lobe measures $0.352(0.228-0.477)$ in length and $0.364(0.265-0.462)$ in width. Each lobe contains 24-26 ovarian follicles. The two lobes are connected to each other by isthmus which measures $0.065(0.048-0.082)$ in length and $0.378(0.364-0.388)$ in width.Uterus is wide convoluted tube, widens and filled with numerous eggs open separately outside the body by uterine pore and measures $0.167(0.159-0.174)$ in length and 0.034(0.0230.045 ) in width. Uterine pore is medium, rounded and measures 0.038 in diameter.The eggs are operculated oval in shape and measures $0.181(0.172-0.191)$ in length and $0.220(0.210-0.230)$ in width. Vitellaria are granular and corticular in position.

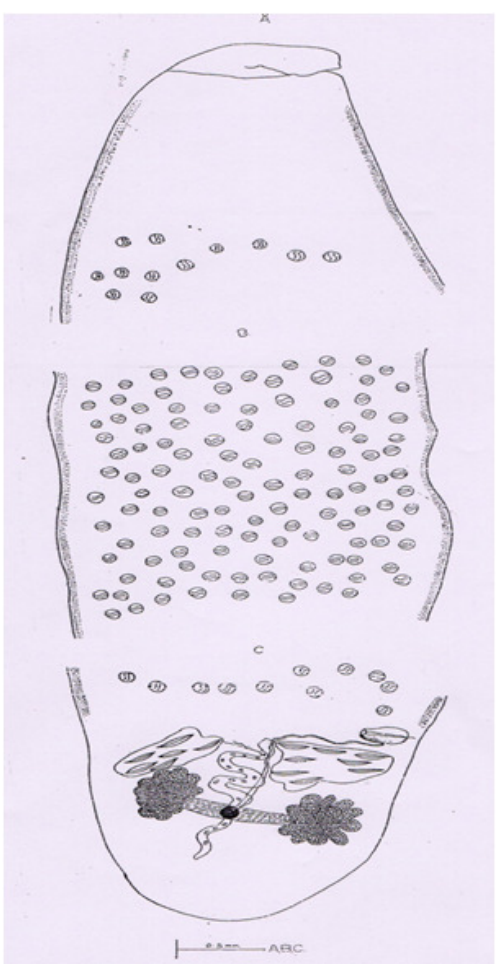

Fig: Lytocestus godavariensis n.sp. A: Ante rior region, B: Middle region, C: Pos te rior region

\section{Discussion}

The present worm has head long, well marked off from the body. Testes numerous (400-500) in numbers, per-ovarian, placed centrally, evenly distributed, oval in shape. Cirrus pouch small, oval, pre-ovarian, transversally placed, cirrus straight thin,vagina long, coiled tube, vas deferens short, thin. Genital pores small, oval, obliquely placed. Ootype is small, oval situated between ovarian lobes. Ovary bilobed, on posterior side, each lobe contains 24-26 ovarian follicles, two lobes connected to each other by isthmus. Uterus wide convoluted tube filled with nume rous eggs. Uterine pore is median and rounded. Eggs are operculated, oval in shape. Vitellaria are granular and corticular in position.

The present worm differs from $L$. indicus which is having length of the body 27 to 40 and width of the same 0.30 to 0.50 , testes $230-270$ in numbers, round in shape, extends up to the cirrus pouch region, vas deferens followed by ductus ejaculates, ovary with numerous follicles connected by bagpipe shaped isthumus, the wall of uterus is thick, coiled and vite rallia follicular, in 2-3 rows on each side. The present cestode differs from L. filiformis, Woodland, 1923 testes is numerous, large rounded in central medulla, ovary bilobed, small containing 6-11 large follicles connected by spindle shaped 
isthmus near posterior margin, vitellaria, follicular, arranged all along testicular and medullary parenchyma, uterus convoluted, tubular pre-ovarian opens by uterine pore anterior to cirrus pouch.The present worm differs from L. indicus, Moghe, 1925 Clarias batrachus, India. In testes 230-270, rounded up to cirrus sac. Some are at lateral side, ovary with numerous follicles connected by big pipe shaped isthmus. Vitellaria small, corticular, rounded in 2-3 round on each lateral side.The parasite differs from L. alestei, Lynsdale, 1956 in testes more or less spherical ovary is bilobed to the posterior side of the body. Vitellaria extend from short distance behind most anterior. Testes upto the anterior tip of the body.The present parasite differs from $L$. biramanicus, Lynsdale, 1956, in testes medullary, extend up to genital pores. Ovary wing like with nume rous follicles. Uterus consist of number of loose cells, the most anterior loop reaching the space between the two genital openings, vitellaria up to the utero-vaginal pore.The present cestode differs from $L$. longicollis, Ramdevi, 1973 which is having the length 10.8-20.0 and width 0.50-0.84, neck long 5.3-5.6, testes 105-140 in numbers, spherical, broadly oval in shape, cirrus pouch oval in shape, vas deferens much convoluted, ovary ' $\mathrm{H}$ ' shaped and vitellaria corticular, large, all around, testes extending from the base of the neck to the anterior tip of the ovary, in 1-2 rows on each lateral side.The present worm differs from L. fossilis, Singh, 1975 in having sucker stumpy neck long, testes numerous, cirrus pouch oval, ovary follicular ' $\mathrm{H}$ ' shaped, vagina and seminal receptaculum absent, uterus completely coiled, uterine coils behind ovarian isthmus. Extension or vitellaria up to posterior end of body. The present parasite diffe rs from $L$. marathwadensis, Shinde and Phad, 1988 in arranged in 2or3 rows; cirrus pouch large, ovary ' $\mathrm{H}$ ' shaped, vitellaria small and oval, single row on lateral side, uterus secular.The present worm differs from L. alii, Jadhav and Gavhane, 1991 in scolex bluntly rounded, cirrus coiled, number of testes 460-480, uterus convoluted tube. The present wall differs from $L$. clariasae, jadhav and Gavhane, 1991 in scolex bluntly rounded, ovary bilobed like bunch of grapes, number of testes 700-750.The present tapeworm differs from $L$. naldurgensis, Kadam, Hiware and Jadhav et. al., 1991 in scolex conical, blunt spatulate, neck short, tes tes 500600 in number, scattered in medullary region, cirrus pouch small, oval, vertical and obliquely placed, ovary bilobed, butterfly shaped, vagina wide tube, uterus wide tube, convoluted, vitellaria follicular, smaller in 3-4 rows. The present worm differs from $L$. teranaensis, Kolpuke and Shinde, 1999 in testes numerous, round about, 1200-1500, pre-ovarian. Ovary bilobed, large, each lobe triangular.The present worm differs from L. caryophyllid, Patil and Jadhav, 2002 in head long well marked off from body. Testes numerous, 1425-1475 in numbers, pre-ovarian, evenly distributed, scattered in single field, small oval. Cirrus sac small, oval, pre-ovarian, obliquely placed and ovary bilobed, butterfly shaped, vagina long coiled. Uterus wide, convoluted, transversly situated, filled with eggs. The present cestode differs from $L$. batrachusae in head spatulate, neck long, wide, gonads situated in the posterior region or the worm, testes medium, round pre-ovarian 38004000 in numbers, cirrus pouch large ablong, pre-ovarian, ovary bilobed, butterfly shaped, lobes with irregular margins, vagina wide tube, runs medially, ootype medium, oval, runs posterior to isthmus; ge nital pores small, oval, central in position, vitellaria small, oval arranged in two rows.The present parasite differs from $L$. shindei, Khadp, Jadhav and Suryavanshi, 2004 in testes about 350-360, ovary bilobed, butterfly shaped near posterior region, uterus wide, convoluted tube transversly situated, filled with numerous eggs, vitellaria granular and corticular.The present worm differs from $L$. nagapurensis, Shinde et. al., 2004 in having spatulate scolex, neck short, broader than long, testes 1100-1150, oval, vas deferens medium, thin, coiled, cirrus pouch medium, ovary bilobed with numerous oval follicles, connected by isthmus, vagina long, thin tube.The present worm differs from $L$. clariae, Tandon, 2005 in testes oval about 270495 in numbers, ovary bilobed ' $H$ ' shaped and vitelline follicles ovoid, pre-ovarian in two rows.The present parasite differs from $L$. attenuates, Tandon et. al. 2005 in having testes 155-398, ovary bilobed and follicular inverted 'A' shaped. Vitallaria ovoid, pre-ovarian arranged in two ropws.The present worm is differs from $L$. assamensis, Tandon et. al., 2005 in testes large, about 266-565 in numbers, ovary bilobed, inverted 'A' shaped, vitalline follicles cortical. The present parasite differs from $L$. heteropneustii, Tondon et. al., 2005 in testes ovoid, large about 235-340 in numbers, ovary bilobed, vitelline follicles ovoid, spherical, cortical in deposition.

The above noted characters are valid enough to accommodate these worms as a new species Lytocestus godavariensis $\mathrm{n}$. sp. Named 
after the well known river Godavari which is ganges of South india, from where the author collected the worm.

\section{Acknowledgment}

The authors are greatful to Principal, S.S.G.M College, Sonai, Kopargaon, DistAhmednagar for providing laboratory and library facilities during the course of study.

\section{References}

Al KAWARI, KALTHAM, S.R. AND MOSTAFA M. RAMADAN, J.W.(1954): Biodiversity of helminth parasites of Fishes in the Arabian Gulf with special reference to digentic trematodes a cestode Qutar Uni. Sci. J. 141-153.

CHINCHOLIKAR L.N. AND SHINDE G.B. (1976): On a new species of Circumoncobothrium shindei, 1986 from freshwater fish, M.U.J. Sci. No. Sci. 16(9):183-188.
DESHMUKH V.H., NANAWARE S.S., SHINDE S.M. AND BHURE D.B. (2013): Studies on prevalence of cestode parasites of freshwater fishes from Nanded region (M.S.) India, Indian J. of Appl. Res. Vol:III, I: 10 .

FRANTISEK MORAVEC (2001): Common sculpin Cotto gobio as a natural paratenic host of Proteocephalus longiclis(Cestoda: Proteociphalidae), a parasite of salmonids, in Europe. Dis. Aquat. Org. 45:155-158

HIWARE C.J. AND JADHAV B.V. (2002): Intestinal histopathology of Clarias batrachus (Linn.) parasitized by Caryophyllaeid cestode. J.Inland Fish. Soc. India, 34(2): 30-35.

HIWARE C.J. (2010): The occurance of cestode parasites collected from some fre shwater fishes of Maharashtra state, India, Trends Research in Science and Technology2 (1): 31-38. 